\title{
Assessment of economic traits' inheritance of winter rye at intraspecific hybridization
}

\author{
Elena Parfenova*, Elena Utkina, Natalia Nabatova, Marina Shamova, and Maria Zhukova \\ Federal Agrarian Research Center of the North-East named after N. V. Rudnitsky, Lenina st., 166a, \\ 610007, Kirov, Russian Federation
}

\begin{abstract}
Intraspecific hybridization in winter rye selection (Secale cereale $L$. ssp. cereale) is a source of intrapopulation genotypic variability with the possibility of using the effect of interpopulation heterosis. The inheritance of the crop yield, the regeneration degree after overwintering and the weight of 1000 grains in reciprocal and back winter rye $F_{1}$ intervarietal hybrids was established. Different types of inheritance prevailed in reciprocal and back crossings. The regeneration inheritance and the weight of 1000 grains had a specificity. Traits' overdominance prevailed in reciprocal crossings ( $45 \%$ of hybrids). The yield of reciprocal hybrids was inherited mainly according to the overdominance type (68\% of the hybrids), the weight of 1000 grains - according to the intermediate type $(50 \%)$, regeneration - according to the overdominance type and transitionally - equally $(36 \%$ each). Intermediate traits' inheritance prevailed in back crossings (62\% of hybrids). The rarest type of traits' inheritance was complete dominance of the best parent ( 2 hybrids). $4 \mathrm{~F}_{1}$ hybrids with the greatest overdominance in yield, regeneration, weight of 1000 grains were allocated. The degree of true and competitive heterosis of reciprocal $\mathrm{F}_{1}$ hybrids in terms of yield was determined. The level of true heterosis of $\mathrm{F}_{1}$ hybrids in terms of yield varied within 6-123\%. Economically significant competitive heterosis in terms of yield was established in $7 \mathrm{~F}_{1}$ hybrids.
\end{abstract}

\section{Introduction}

The intraspecific hybridization method is used in the practical breeding of winter rye (Secale cereale L. ssp. Cereale) to create source material with high polymorphism of economic traits and properties. As a result, intrapopulation variability increases, which is required for effective selection [1]. For the rational selection process planning in specific populations, it is necessary to study the features and general patterns of polygenic economic traits' inheritance. Molecular genetic testing of winter rye is aimed at establishing the genetic basis of crop yield, frost and cold resistance, the weight of 1000 grains [2-5]. At the same time, there is insufficient information about the quantitative traits' inheritance during intraspecific hybridization in traditional breeding.

\footnotetext{
* Corresponding author: elka1745@yandex.ru
} 
Establishing the type (character) of quantitative traits' inheritance in intervarietal crossings gives an idea of the expressiveness of the dominant allele. The inheritance type is determined at the hybridological analysis stage of $F_{1}$ plants and parental forms using the degree of phenotypic dominance in the $\mathrm{F}_{1}$ offspring [6]. With regard to polygenic traits in winter rye, the hybrid offspring obtained from the crossing of population varieties will already split in the $F_{1}$ generation [1]. According to the literary data, yield inheritance in simple intervarietal $\mathrm{F}_{1}$ hybrids occurs according to the dominance type of the best parent, as well as according to the overdominance type (heterosis) [7, 8, 9]. Being closely associated with plant regeneration after overwintering, winter resistance in intervarietal $F_{1}$ hybrids was inherited according to an intermediate type [10], a heterotic effect and the dominance of more winter-hardy parental forms were also noted $[7,10]$. In the inheritance of the weight of 1000 grains, cases of intermediate inheritance and deviation towards the maternal form were noted [11]. When crossing varieties contrasting by the weight of 1000 grains, a large graininess was dominating in $\mathrm{F}_{1}$ [7].

The purpose of the research was to establish the yield inheritance type, regeneration, and the weight of 1000 grains in reciprocal and back $\mathrm{F}_{1}$ hybrids of winter rye; to determine the degree of true and competitive heterosis of reciprocal $F_{1}$ hybrids; to search for $F_{1}$ hybrids with the highest phenotypic dominance of economic traits.

\section{Materials and methods}

The research material was $F_{1}$ hybrids of winter rye obtained in reciprocal and back crossing of population varieties of the FASC of the North-East $\left(\mathrm{P}_{1}\right)$ and out-of-region selection $\left(\mathrm{P}_{2}\right)$ with the use of manual castration of the maternal form. $\mathrm{F}_{0}$ seeds were sown in a nursery for studying $F_{1}$ hybrid (plants) on the experimental field of the FASC of the North-East (Kirov). The experiment had 2-fold repetition, plant nutrition area $-45 \mathrm{~cm}^{2}$, standard variety - Falenskaya 4. The study used the data from a field experiment on the study of 29 $F_{1}$ hybrids (22 reciprocal, 7 back crossings) obtained in 2013, 2016, 2018, 2019. In direct reciprocal crossings, the maternal form was the varieties bred by the FASC of the NorthEast.

Accounting was carried out according to yield, weight of 1000 grains, regeneration of $F_{1}$ hybrids and parental forms. The regeneration degree was determined as the percentage of overwintered plants to the number of plants on the plot before wintering. The data were processed by the single-factor analysis of variance. The phenotypic variability of traits was compared by the coefficient of variation $(\mathrm{V}, \%)$.

The character of traits' inheritance was established by calculating the degree of phenotypic dominance $\left(\mathrm{h}_{\mathrm{p}}\right)$

$$
h_{p}=\left(F_{l}-M P\right) /(P-M P)
$$

where $F_{1}$ is the average value of the hybrid's trait, $P$ is the average value of the best parental form's trait, MP - the average trait value of both parental forms [12]. Gradings: $h_{p}<-1$ depression; $-1<h_{p}<1$ - intermediate trait inheritance; $h_{p}=1$ - complete dominance of the best parent; $h_{p}>1$ - overdominance (heterosis).

True heterosis $\left(\mathrm{H}_{\text {true }}\right)$ was calculated by the formula [11]:

$$
H_{\text {true }}=\left(\left(F_{1}-P\right) / P\right) * 100
$$

where $F_{1}$ is the value of the hybrid trait, $\mathrm{P}$ - the trait value of the best parental form. Competitive heterosis $\left(\mathrm{H}_{\text {com }}\right)$ was calculated using the formula [11]:

$$
H_{\text {com }}=\left(\left(F_{1}-S t\right) / S t\right) * 100
$$


where St is the value of the standard variety trait.

The optimal conditions for the hydrothermal regime were formed in 2013 and 2016. Excessively humid conditions for winter rye vegetation were noted in 2018 and 2019. In 2018 , repeated snowfall in the last decade of April slowed down the resumption of plant vegetation, which subsequently led to a delay in the passage of all development phases by 7-10 days.

\section{Results and discussion}

The yield (368 $\mathrm{g} / \mathrm{m}^{2)}$ and the weight of 1000 grains (37.3 $\left.\mathrm{g}\right)$ of $\mathrm{F}_{1}$ hybrids by an average of 4 years have been at the level of the average values of the best parental forms $\left(289 \mathrm{~g} / \mathrm{m}^{2}\right.$ and $38.5 \mathrm{~g}$, respectively). The differences between the average regeneration values of hybrids and parental forms were insignificant at 5\% significance level. On average for 4 years, the parental forms of the FASC of the North-East selection were characterized by a higher yield and regeneration but were inferior in grain size to the parental forms of the outof-region selection (Table 1).

Table 1. Average values and phenotypic variability of traits.

\begin{tabular}{|c|c|c|c|c|c|c|c|c|c|c|c|c|}
\hline \multirow[b]{2}{*}{ Years } & \multicolumn{4}{|c|}{ Crop yield, $\mathrm{g} / \mathrm{m}^{2}$} & \multicolumn{4}{|c|}{ Regeneration, \% } & \multicolumn{4}{|c|}{ Weight of 1000 grains, $\mathrm{g}$} \\
\hline & $\begin{array}{c}\text { by } \\
\text { experiment }\end{array}$ & $P_{1}$ & $\mathrm{P}_{2}$ & $\mathrm{~F}_{1}$ & $\begin{array}{c}\text { by } \\
\text { experiment }\end{array}$ & $\mathrm{P}_{1}$ & $\mathrm{P}_{2}$ & $\mathrm{~F}_{1}$ & \begin{tabular}{|c|} 
by \\
experiment
\end{tabular} & $\mathrm{P}_{1}$ & $\mathrm{P}_{2}$ & $\mathrm{~F}_{1}$ \\
\hline 2013 & 339 & 334 & 156 & 417 & 73 & 83 & 38 & 79 & 30.7 & 28.5 & 34.6 & 30.7 \\
\hline 2016 & 148 & 164 & 112 & 203 & 52 & 57 & 38 & 57 & 41.7 & 39.4 & 42.7 & 42.9 \\
\hline 2018 & 232 & 318 & 79 & 294 & 26 & 26 & 39 & 18 & 36.7 & 35.8 & 38.6 & 38.2 \\
\hline 2019 & 467 & 341 & 432 & 556 & 69 & 68 & 62 & 73 & 37.2 & 35.9 & 38.0 & 37.2 \\
\hline Average & 297 & 289 & 195 & 368 & 55 & 59 & 44 & 57 & 36.4 & 34.9 & 38.5 & 37.3 \\
\hline $\mathrm{V}, \%$ & 47 & 29 & 83 & 42 & 39 & 41 & 27 & 48 & 12 & 13 & 9 & 13 \\
\hline $\mathrm{LSD}_{05}$ & & 105 & & & & NS & & & & 1.5 & & \\
\hline
\end{tabular}

There was a high phenotypic variability of $\mathrm{F}_{1}$ hybrids in terms of yield $(\mathrm{V}=42 \%)$, regeneration $(\mathrm{V}=48 \%)$, and average - by weight of 1000 grains $(\mathrm{V}=13 \%)$.

The type of trait inheritance was established in 22 reciprocal $F_{1}$ hybrids. At the same time, the absence of a general pattern of hereditary information transfer from parents to offspring was noted. Various inheritance types were observed - from depression $\left(h_{p}=-4.5\right)$ to overdominance $\left(\mathrm{h}_{\mathrm{p}}=30.6\right)$, tab. 2 .

Table 2. Inheritance of traits by reciprocal $\mathrm{F}_{1}$ hybrids

\begin{tabular}{|c|c|c|c|c|c|c|c|}
\hline \multirow{3}{*}{ Years } & \multirow{3}{*}{ Combinations } & \multicolumn{6}{|c|}{$h_{p}$} \\
\hline & & \multicolumn{2}{|c|}{ crop yield } & \multicolumn{2}{|c|}{ regeneration } & \multicolumn{2}{|c|}{$\begin{array}{c}\text { weight of } 1000 \\
\text { grains }\end{array}$} \\
\hline & & 1 & 2 & 1 & 2 & 1 & 2 \\
\hline \multirow{2}{*}{2013} & Rada x Krona & 2.2 & 1.8 & 1.1 & 0.5 & -0.3 & -0.2 \\
\hline & Rushnik x Tatiana & 2.0 & 1.6 & 0.4 & 1.3 & 0.03 & 0.6 \\
\hline \multirow{3}{*}{2016} & Grafinya 2D x Tatiana & -0.3 & 0.5 & 1.2 & 0.7 & -0.5 & 0 \\
\hline & Triumf $\mathrm{x}$ Tatiana & 2.0 & 5.8 & 0.6 & 0.7 & 0.7 & 1.2 \\
\hline & Kiprez x Tatiana & 3.2 & 6.8 & 2.0 & 11.5 & 1.0 & -0.5 \\
\hline \multirow{2}{*}{2018} & Kiprez x Volkhova & 0.4 & 0.8 & -2.1 & -3.0 & 18.2 & 8.6 \\
\hline & Falenskaya 4 x Volkhova & 2.2 & 10.4 & -2.4 & -2.3 & -2.3 & 11.4 \\
\hline \multirow{4}{*}{2019} & Falenskaya 4 x Falenskaya universal'naya & 0.6 & 0.1 & 3.4 & 0.3 & 0.3 & 1.2 \\
\hline & Falenskaya 4 x Talovskaya 41 & 7.2 & 4.6 & 26.7 & 30.6 & -0.02 & -0.1 \\
\hline & Rushnik x Volkhova & 1.3 & 3.9 & -4.5 & -1.5 & -1.0 & -1.9 \\
\hline & Flora x Falenskaya universal'naya & 1.5 & 0.8 & 0.6 & -0.7 & 4.2 & 3.8 \\
\hline
\end{tabular}


Overdominance of yield was observed in $15 \mathrm{~F}_{1}$ hybrids $(68 \%)$, in 7 combinations - in both directions of crossing. Intermediate inheritance was noted in $7 \mathrm{~F}_{1}$ hybrids $(32 \%)$. Regeneration was equally inherited by the intermediate type and the overdominance type ( 8 hybrids each). Overdominance in regeneration was more often manifested in direct crossings (5 hybrids). In unfavorable conditions of vegetation resuming in 2018, depression was noted in all hybrids. The weight of 1000 grains were inherited by an intermediate type in 11 hybrids (50\%). Overdominance of large graininess was observed in 7 hybrids $(32 \%)$, including in 5 hybrids in backcrossings. Full dominance of the best parent (Tatiana variety) was noted in 1 hybrid. Reciprocal hybrids with the highest overdominance of yield $\left(\mathrm{F}_{1}\right.$ Volkhova x Falenskaya 4), regeneration ( $F_{1}$ Talovskaya 41 x Falenskaya 4), weight of 1000 grains ( $\mathrm{F}_{1}$ Kiprez $x$ Volkhova) were identified.

The traits' inheritance in backcrosses obtained in back crossings is presented in Table 2.

Table 2. Inheritance of traits in $\mathrm{F}_{1}$ backcrosses.

\begin{tabular}{|c|c|c|c|c|}
\hline \multirow[b]{2}{*}{ Years } & \multirow[b]{2}{*}{ Combinations } & \multicolumn{3}{|c|}{$h_{p}$} \\
\hline & & $\begin{array}{l}\text { crop } \\
\text { yield }\end{array}$ & $\begin{array}{l}\text { reg } \\
\text { ener } \\
\text { ation }\end{array}$ & $\begin{array}{c}\text { weight of } \\
1000 \\
\text { grains }\end{array}$ \\
\hline \multirow{2}{*}{2013} & (F 1 Snezhana $2 \times$ Falenskaya 4$) \times$ Falenskaya 4 & 0.4 & -0.3 & 0.6 \\
\hline & $\left(\mathrm{F}_{1}\right.$ Snezhana 3 x Falenskaya 4) x Falenskaya 4 & -1.6 & -11.0 & 0.3 \\
\hline \multirow{3}{*}{2016} & (F 1 ( $\mathrm{F}_{1}$ Rada $\mathrm{x}$ Crona) $\mathrm{x}$ Tatiana) $\mathrm{x}$ Tatiana & -10.0 & 0.02 & 8.1 \\
\hline & (F 1 Grafinya x Moskovskaya 12) x Moskovskaya 12 & 0.6 & 1.0 & -0.2 \\
\hline & (F 1 Grafinya x Moskovskaya 12) x Grafinya & 0.4 & 0.7 & 1.2 \\
\hline \multirow{2}{*}{2019} & $\left(F_{1}\right.$ Volkhova x Falenskaya 4) x Falenskaya 4 & 0.1 & 0.4 & -7.7 \\
\hline & (F 1 Falenskaya 4 x Volkhova) x Volkhova & 0.2 & -2.3 & 0.6 \\
\hline
\end{tabular}

The yield and weight of 1000 grains in most backcrosses were inherited intermediately ( 5 and 4 hybrids, respectively). Overdominance by the weight of 1000 grains was observed in 2 hybrids. The inheritance of the regeneration ability was also specific and manifested itself in the hybrid offspring in different ways: inheritance by an intermediate type was noted in 4 hybrids, dominance - the best parent - 1 hybrid, depression - 2 hybrids. In the combination ( $F_{1}$ Grafinya $x$ Moskovskaya 12) x Moskovskaya 12, the complete dominance of the best parent in regeneration (maternal form) was manifested. A hybrid $F_{1}$ ( $F_{1}$ Rada $x$ Crona) $\mathrm{x}$ Tatiana) $\mathrm{x}$ Tatiana with the highest over-dominance of the 1000 -grains weight trait was identified.

The indicator of competitive and true heterosis gives an assessment of the economic prospects of $\mathrm{F}_{1}$ hybrids with over-dominance in terms of yield (Table 3 ).

Table 3. The degree of true and competitive heterosis of $\mathrm{F}_{1}$ hybrids by yield.

\begin{tabular}{|c|l|c|c|c|c|}
\hline \multirow{2}{*}{ Years } & \multicolumn{2}{|c|}{ Combinations } & \multicolumn{2}{c|}{$\mathrm{H}_{\text {true, }} \%$} & \multicolumn{2}{c|}{$\mathrm{H}_{\text {com }}, \%$} \\
\cline { 3 - 6 } & & 1 & 2 & 1 & 2 \\
\hline \multirow{2}{*}{2013} & Rada x Krona & 40 & 26 & 23 & 11 \\
\cline { 2 - 6 } & Rushnik x Tatiana & 21 & 12 & 7 & - \\
\hline \multirow{2}{*}{2016} & Triumf x Tatiana & 16 & 78 & 0 & 53 \\
\cline { 2 - 6 } & Kiprez x Tatiana & 37 & 101 & - & 17 \\
\hline 2018 & Falenskaya 4 x Volkhova & 99 & 58 & 193 & 132 \\
\hline \multirow{2}{*}{2019} & Falenskaya 4 x Talovskaya 41 & 6 & 68 & 30 & 106 \\
\cline { 2 - 6 } & Rushnik x Volkhova & 7 & - & 202 & - \\
\cline { 2 - 6 } & Flora x Falenskaya universal'naya & 7 & - & \\
\hline
\end{tabular}

The true heterosis level of $F_{1}$ hybrids varied from 6 to $123 \%$. The maximum true heterosis was observed in the $F_{1}$ hybrid Volkhova $x$ Falenskaya 4 (123\%). Differences between reciprocal hybrids in terms of true heterosis ranged from 35 to $91 \%$. Economically 
significant competitive heterosis of more than $25 \%$ was established in 7 hybrids: $F_{1}$ Tatiana x Triumf, $F_{1}$ Volkhova x Falenskaya 4, $F_{1}$ Falenskaya 4 x Talovskaya 41, $F_{1}$ Talovskaya 41 x Falenskaya 4, F $F_{1}$ Rushnik x Volkhova, $F_{1}$ Volkhova x Rushnik, F Flora x Falenskaya universal'naya.

\section{Conclusions}

In terms of yield and weight of 1000 grains for an average of 4 years, $F_{1}$ hybrids were at the level of average values of the best parental forms. The differences in the regeneration of hybrids and parental forms were insignificant (at 5\% significance level).

A different type of traits' inheritance was established: from depression $\left(h_{p}=-10.0\right)$ to overdominance $\left(\mathrm{h}_{\mathrm{p}}=30.6\right)$. Different types of inheritance prevailed in reciprocal and back crossings. In reciprocal crossings, overdominance was most common (45\% of crossings), an intermediate type of inheritance prevailed in backcrossings ( $62 \%$ of crossings). Complete dominance of the best parent was rare ( $2 \mathrm{~F}_{1}$ hybrids).

The specific character of regeneration inheritance and the weight of 1000 grains was observed in reciprocal and back crossings. The yield of reciprocal hybrids was inherited mainly according to the type of overdominance ( $68 \%$ of $F_{1}$ hybrids), the weight of 1000 grains - according to the intermediate type (50\% of hybrids), regeneration was inherited according to the intermediate type and the overdominance type equally (36\% of the hybrids). 4 hybrids with the maximum yield overdominance ( $F_{1}$ Volkhova $x$ Falenskaya 4$)$, regeneration ( $F_{1}$ Talovskaya 41 x Falenskaya 4), weight of 1000 grains ( $F_{1}$ Kiprez $x$ Volkhova, $F_{1}$ ( $F_{1}$ Rada $x$ Crona) $x$ Tatiana) $x$ Tatiana). 7 hybrids with economically significant competitive heterosis in yield were identified $\left(\mathrm{F}_{1}\right.$ Tatiana $\mathrm{x}$ Triumf, $\mathrm{F}_{1}$ Volkhova x Falenskaya 4, $F_{1}$ Falenskaya 4 x Talovskaya 41, $F_{1}$ Talovskaya 41 x Falenskaya 4, $F_{1}$ Rushnik x Volkhova, $F_{1}$ Volkhova x Rushnik, F $F_{1}$ Flora x Falenskaya universal'naya).

\section{References}

1. A.A. Goncharenko, Topical issues of winter rye breeding, Moscow (2014)

2. W.J. Jung, Y.W. Seo, Gene, 684, 82-94 (2019) doi: 10.1016/j.gene.2018.10.055

3. W. Erath, E. Bauer, D.B. Fowler et al., Theor. Appl. Genet., 130, 2151-2164 (2017) doi: 10.1007/s00122-017-2948-7

4. E. Bauer, T. Schmutzer, I. Barilar et al. Plant J. 89(5), 853-869 (2017) doi: 10.1111/tpj.13436

5. G. Wricke, Plant Breeding, 121 (1), 26-28 (2002) doi: 10.1046/j.14390523.2002.00666.x

6. V.A. Dzyuba, L.V. Esaulova, I.N. Chukhir, E.N. Lapina, Grain Economy of Russia, 3, 8-13 (2012) www.elibrary.ru/item.asp?id=17794893

7. A.A. Goncharenko, S.V. Krakhmalev, A.V. Makarov, S.A. Ermakov Agricultural Biology, 50 (1), 76 (2015) doi: 10.15389/agrobiology.2015.1.75rus

8. E.A. Zmievskaya, D.K. Egorov, Selection and seed production, 108, 92-98 (2015) www.irbis-nbuv.gov.ua/cgi-bin/irbis_nbuv/cgiirbis_64.exe?/selinas_2015_108_14.pdf

9. A.A. Goncharenko, S.V. Krakhmalev, S.A. Ermakov, A.V. Makarov, T.V. Semenova, $\begin{array}{lllll}\text { V.N. Tochilin, Legumes and cereals, 2, 99-107 (2012) } & \end{array}$ www.elibrary.ru/item.asp?id=19132244

10. A.A. Goncharenko, S.V. Krakhmalev, Grain Economy of Russia, 2, 25-37 (2012) www.elibrary.ru/item.asp?id=177191051 
11. V. D. Kobylyansky, Rye. Genetic Foundations of Breeding (Kolos, Moscow, 1982)

12. J.B. Griffing, Genetics, 35, 303-321 (1950) 